\title{
THE SPECTRAL PROPERTIES AND PHOTOSTABILITY OF DNA, RNA, AND OLIGONUCLEOTIDES
}

\author{
V.YU. KUDRYA, V.M. YASHCHUK \\ Taras Shevchenko National University of Kyiv \\ (4b, Prosp. Academician Glushkov, Kyiv 03022, Ukraine; e-mail: kudrya@univ. kiev. ua)
}

PACS 87.15.mq, 82.50.Hp,

78.47.jd, 78.55.-m

(c) 2012

The present work discusses the results of comparative investigations of the optical absorption, luminescence, and photostability of the biomacromolecules (DNA, RNA), as well as synthetic poly- and oligonucleotides. The separate nucleotides in DNA and RNA are examined as almost independent absorbing centers. It is confirmed that the main triplet excitons traps responsible for the DNA phosphorescence emission are AT-complexes in DNA. In contrast to DNA, the main triplet excitons traps in RNA are adenosine bases. These bases are the most photostable against UV-irradiation as compared with all other nucleotides in both DNA and RNA. The fact of the photostability of adenosine bases and the AT-complex provides the existence of the DNA/RNA self-protection mechanisms against a damage caused by UV-irradiation. It is found the deoxyribonucleotides are more photostable than the corresponding ribonucleotides. So, the results presented here show that DNA is more photostable than RNA.

\section{Introduction}

It is known the macromolecules of ribonucleic acids (DNA and RNA) are the vitally important biopolymer compounds for all living organisms. The main role of these compounds is the long-time storage and the transfer of a genetic information. The electronic properties of these biomacromolecules are manifested in the optical (near biologically active ultraviolet, visual, and near infrared) range and are related to the presence of the $\pi$-electronic groups in nucleotide cells in their chains. This gives the ground to apply the optical spectroscopy methods to the RNA/DNA electronic structure investigations. The biomacromolecules are of the type of macromolecules, in which the $\pi$-electron systems are localized in separate groups and, as a result, their energy structure is determined mainly by individual properties of such groups. In view of the facts mentioned above, the optical absorption and luminescent spectra of the biomacromolecules can be used for the evaluation of positions of the first excited singlet and triplet energy levels of the biomacromolecules and the identification of localization centers for migrating electronic excitations in these compounds [1-9].
The first steps in the spectral investigations of nucleic acids were carried out in the 1960s [1-4]. The main objects of these investigations were the optical absorption, fluorescence, and phosphorescence of the nucleotides and DNA. One of the main disputes in these works was the question concerning the nature of the traps of triplet excitons in DNA, because just these excitations cause the initiation of photochemical reactions (e.g., photodestruction) in the majority of $\pi$-electron-containing compounds. It is clear the transfer of triplet excitons have to lead to the localization of triplet excitons on the cell with the lowest triplet energy level. But there are other ideas in the scientific literature. In [2], it was proved that the DNA phosphorescence is the emission of the ionized $\pi$-electron system of dTMP $\left(T^{-}\right)$. Later in [3], it was determined that the localization of triplet excitons on the neutral dTMP instead $T^{-}$results in the DNA phosphorescence. The facts that the dTMP phosphorescence spectrum is blue-shifted relative to the DNA phosphorescence spectrum and the phosphorescence decay time of the dTMP is at least twice greater than that of DNA $[2,3]$ do not confirm the last version. The poly(dAT) spectrum is more similar to the DNA spectrum $[2,3]$. So, rather thymidine bound to adenosine determines the phosphorescence of DNA. In [5-7], it was proved that the centers responsible for the DNA phosphorescence emission are AT-complexes. There are only a few works about similar investigations of the RNA luminescence nature. In our previous works [8,9], it was shown the centers responsible for the RNA phosphorescence are adenosine bases. The aim of this work is to study the influence of the structure of localization centers for triplet excitations on the photostability of DNA and RNA macromolecules.

\section{Experimental}

The samples of DNA, RNA, $2^{\prime} 5^{\prime} A_{3}$, d(ATC), singlestranded copolymer poly(rArU), and double-stranded copolymer poly $(\mathrm{dAdT})_{2}$ under study are given in a polite manner from Institute of Molecular Biology and 


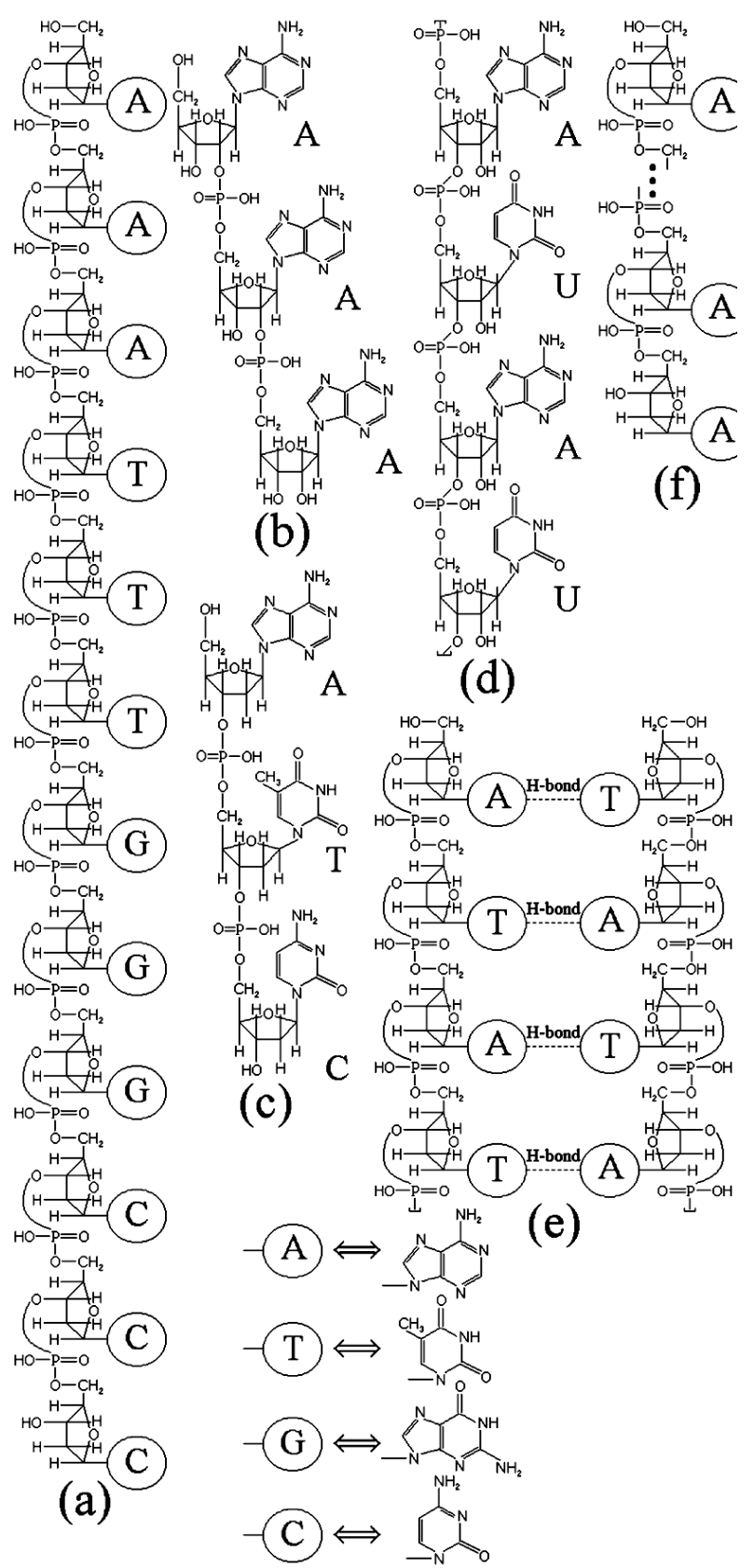

Fig. 1. Chemical formula of d(CCCGGGTTTAAA) $(a), \quad 2^{\prime} 5^{\prime} A_{3} \quad(b), \quad \mathrm{d}($ ATC $) \quad(c), \quad$ single-stranded copolymer poly $(\mathrm{rArU}) \quad(d), \quad$ double-stranded $\quad$ copolymer $\operatorname{poly}(\mathrm{dAdT})_{2}$ $(e)$, d(AAAAAAAAAAAA) $(f)$

Genetics of the NAS of Ukraine. Oligonucleotides d(CCCGGGTTTAAA) and d(AAAAAAAAAAAA) are given in a polite manner from Research Center for Advanced Science and Technology, University of Tokyo, Japan. The nucleotides contained in the investigated poly- and oligonucleotides are bound by $\mathrm{PO}_{4} \mathrm{H}$ phosphate groups in positions $3^{\prime}$ and $5^{\prime}$ (exception is trimer $2^{\prime} 5^{\prime} A_{3}$, where the nucleotides are bound in position $2^{\prime}$ and $\left.5^{\prime}\right)$. The chemical formulae of the studied compounds are presented in Fig. 1.

The optical absorption spectra in the range $200 \div$ $360 \mathrm{~nm}$ were recorded using a spectrophotometer Specord UV VIS. The spectra of fluorescence and phosphorescence in the range $290 \div 620 \mathrm{~nm}$ were recorded at temperatures of $4.2 \div 77 \mathrm{~K}$ using a spectrometer Hitachi MPF-4 and the spectral complex developed in our laboratory on the basis of a spectrometer MDR-2. Photodamage was carried out by the ultraviolet $\mathrm{Hg}$ lamp DRT-1000 irradiation of solutions of the investigated compounds. The optical absorption spectrum of the irradiated sample was recorded on a spectrophotometer Specord UV VIS after a certain exposure time of UVirradiation.

The errors of determination of the positions of absorption and luminescence bands did not exceed $50 \mathrm{~cm}^{-1}$, which is quite acceptable for the investigated broad bands $\left(>1000 \mathrm{~cm}^{-1}\right)$. The measurement errors of the luminescence intensity of the same sample did not exceed $2 \%$.

\section{Results and Discussion}

According to our previous investigations [5-8], the optical absorption spectra of DNA, RNA, and oligonucleotide d(CCCGGGTTTAAA) are very close to the additive sum of the absorption spectra of the corresponding nucleotides (Fig. 2). That is why the nucleotides manifest themselves as practically independent absorbing centers in DNA, and all the electronic processes are started with the first separately excited nucleotides-cells. In this work, the samples of transport RNA (tRNA), oligo-RNA, and a short fragment of yeast RNA are investigated. The absorption spectra of these RNAs coincide with one another (Fig. 2, curve 3); they are also close to the spectra of DNA, d(CCCGGGTTTAAA), and the sum of the nucleotides absorption spectra. So, the nucleotides are practically independent absorbing centers in RNA, as well as in DNA. That is why the nucleotides can be used to build the hierarchy of the RNA energy levels. Using our previous data $[8,9]$, the positions of the first excited energy levels of RNA are confirmed; they were obtained as the singlet level $\left(S_{1}\right)$ at the intersection of the absorption and fluorescence spectral curves and the triplet level $\left(T_{1}\right)$ at the blue edge of the phosphorescence spectrum (Fig. 3). It is worth to note that the mutual location of both $S_{1}$ - and $T_{1}$-levels of ribonu- 


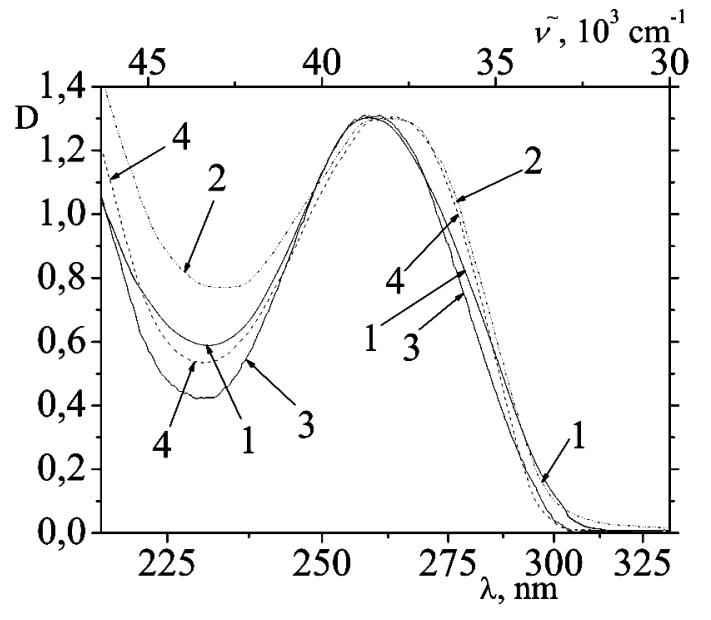

Fig. 2. Optical absorption spectra of DNA (1), d(CCCGGGTTTAAA) (2), RNA (3), and the sum (equimolar concentration) of the absorption spectra of nucleotides dAMP, dTMP, dGMP, and dCMP (4)

cleotides rAMP, rGMP, rCMP is the same as those of deoxyribonucleotides dAMP, dGMP, and dCMP [5-9]. This fact can confirm, basically, the versions of uniformity of the photophysical processes in DNA and RNA. The exceptions are dTMP and rUMP, which are not exact analogs of each other. Thus, the positions of the RNA energy levels should facilitate the electronic energy transfer by triplet levels (with the subsequent localization and deactivation) to the base, which has the lowest triplet level, namely, adenine base.

The positions of the first excited singlet and triplet energy levels were obtained at two temperatures: $T=$ $4.2 \mathrm{~K}$ and $T=77 \mathrm{~K}$. The reason for this, on the one hand, is the necessity to compare our results with the results of DNA/RNA luminescent investigations in [4], which were carried out at $T=77 \mathrm{~K}$. On the other hand, the edges and maxima of the luminescence spectra curves at $T=4.2 \mathrm{~K}$ are sharper, which simplifies the determination of the energy levels positions.

It was previously shown by us [5-7], in contrast to the absorption, that the phosphorescence of DNA and oligonucleotide d(CCCGGGTTTAAA) is not the emission of one separate nucleotide-cell. This is a result of the deactivation of a complex like the exciplex formed between neighboring adenosine (A) and thymidine (T) cells. This was proved by comparative phosphorescence studies of a number of compounds containing the AT-sequence: the phosphorescence spectral curves of the DNA, double-stranded polymer poly $(\mathrm{dAdT})_{2}$, oligomer d(CCCGGGTTTAAA), trimer d(ATC), and
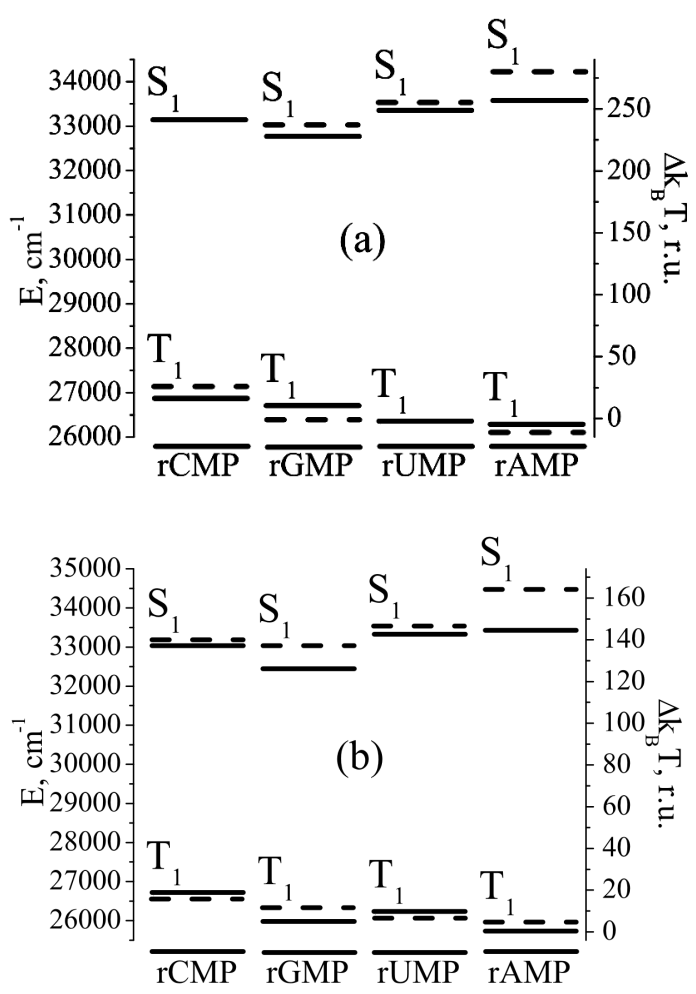

Fig. 3. Schemes of positions of the first singlet and triplet energy levels of the ribonucleotides (straight) and the deoxyribonucleotides (dash) at $T=4.2 \mathrm{~K}(a)$ and $T=77 \mathrm{~K}(b)$ (as an analog for rUMP, dTMP was given)

dimer d(AT) are very close (Fig. 4) at both temperatures of the investigations.

Based on the above-mentioned consideration, we assume that a complex similar to AT has to be formed in RNA (whose chemical and partly energy structures are similar to the DNA structures). We have investigated two samples of RNA (tRNA and oligo-RNA) and trimer $2^{\prime} 5^{\prime} A_{3}$, in which nucleotides are bound in the "unnatural" way in positions $5^{\prime}$ and $2^{\prime}$. The phosphorescence spectrum of $2^{\prime} 5^{\prime} A_{3}$ at $T=4.2 \mathrm{~K}$ (Fig. 5, a, curve 3) for the main maxima of electron-vibrational structure practically coincides with the spectrum of a rAMP monomer, but with a sharper structure of these maxima. In our opinion, the increasing number of cells leads to a rigid fixation of the cells by neighbors and, consequently, to a decrease of the number of degrees of freedom. The further increase of the number of cells (e.g., oligomer d(AAAAAAAAAAAA), Fig. 5, $a$, curve 5) leads to more structured main peaks and the shifted $(\sim 1 \mathrm{~nm}) 1$-st and 2-nd peaks toward the shorter wavelengths. In addition, a small redistribution of the intensities of these 

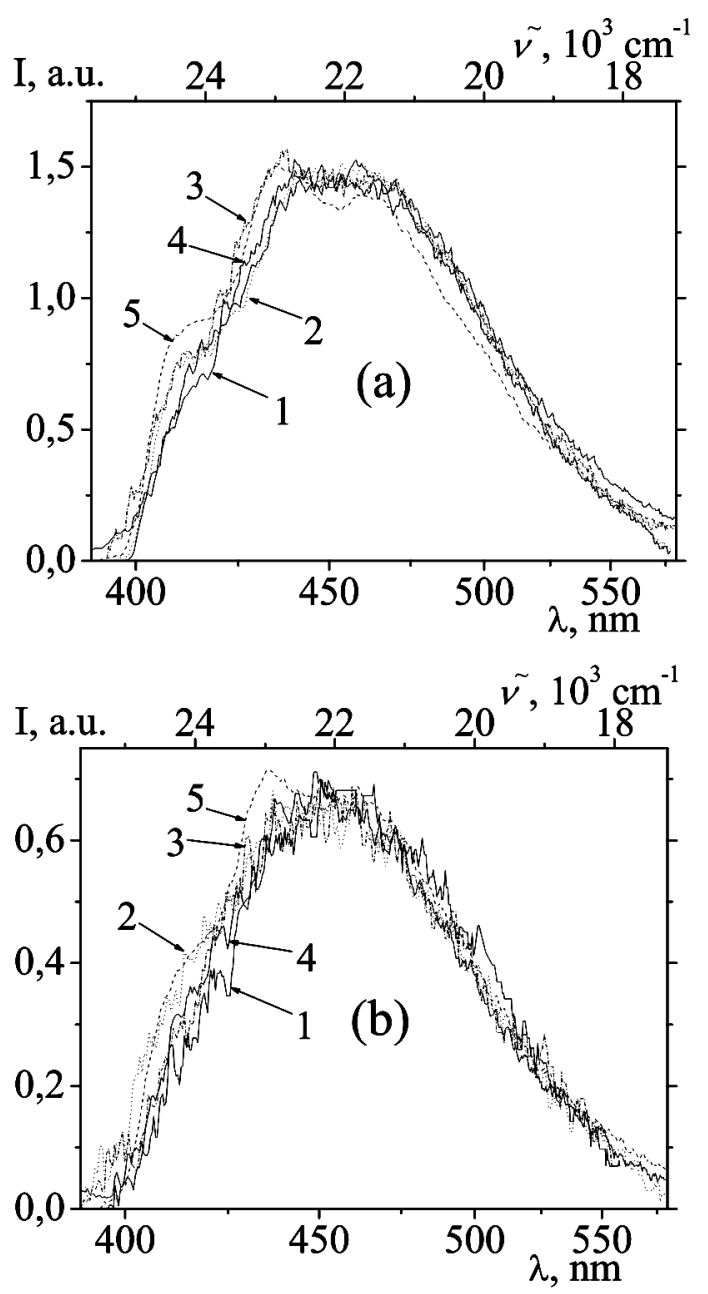

Fig. 4. Phosphorescence spectra at $T=4.2 \mathrm{~K}(a)$ and $T=77 \mathrm{~K}$ (b): DNA (1), d(CCCGGGTTTAAA) (2), poly(dAdT) $)_{2}$ (3), $\mathrm{d}(\mathrm{ATC})(4)$, and $\mathrm{d}(\mathrm{AT})(5)$. Excitation at $300 \mathrm{~nm}$. Water solutions, $C=10^{-4} \mathrm{M}$

peaks is observed, which is standard for the majority of $\pi$-electron-containing compounds (see, e.g., $[10,11]$ for the copolymers of vinylcarbazole (VCa) with methyl methacrylate with different average distances between $\pi$-electron-containing cells of VCa). The phosphorescence spectrum of tRNA (Fig. 5,a, curve 1) possesses the adenine structure too, but the 1-st and 2-nd maxima are shifted toward the shorter wavelengths by $3 \mathrm{~nm}$, which cannot be attributed already to errors. This fact can be explained by the influence of residual $\pi$-electroncontaining amino acids contained in the proteins accompanying to nucleic acids. In addition, the wide short$(\sim 370 \mathrm{~nm})$ and long-wave $(\sim 500 \mathrm{~nm})$ bands are also, in our opinion, indicate the influence of the residual amino acids. The phosphorescence spectrum of oligo-
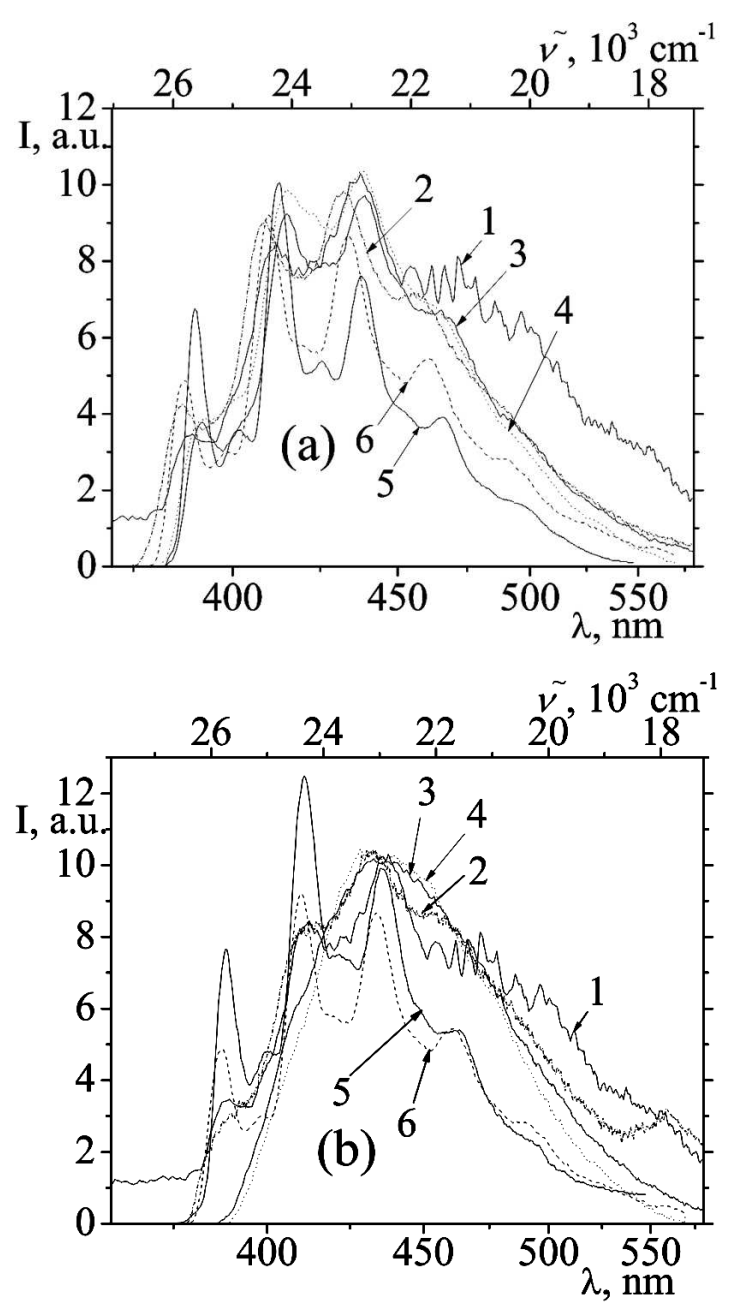

Fig. 5. Phosphorescence spectra at $T=4.2 \mathrm{~K}(a)$ and $T=$ $77 \mathrm{~K}(b)$ : tRNA (1), oligo-RNA (2), $2^{\prime} 5^{\prime} A_{3}$ (3), $\operatorname{rAMP}(4)$, d(AAAAAAAAAAAA) (5), and poly(rArU) (6). Excitation at $260 \mathrm{~nm}$. Water solutions, $C=10^{-4} \mathrm{M}$

RNA (Fig. 5, a, curve 2) manifests the adenine structure, but it is completely shifted toward the smaller wavelengths relative to those of rAMP and $2^{\prime} 5^{\prime} A_{3}$ by $\sim 5 \mathrm{~nm}$. The spectral range of the oligo-RNA phosphorescence is rather close to the spectral range of the phosphorescence of the single-stranded copolymer poly(rArU) (Fig. 5,a, curve 6) (specially studied to elucidate the RNA phosphorescence nature). Thus, the spectral manifestation of the weak interaction between neighbor cells of RNA leading to a rigid fixation of the nucleotides-cells is the spectral shift of the whole phosphorescence spectrum by $\sim 4 \div 5 \mathrm{~nm}$. Resuming the data presented above, the center of the localization and deactivation of the triplet excitons in all investigated compounds is the adenine cell. Thus, no complex similar to the AT-complex in the 

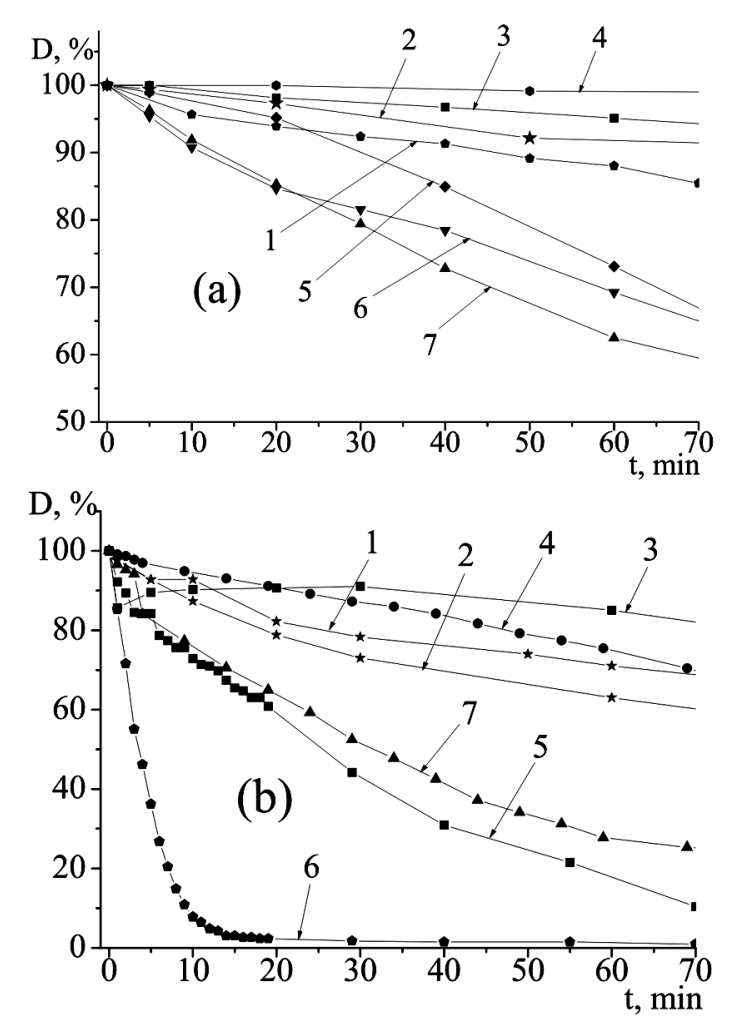

Fig. 6. Dependences of the optical density of the long-wave absorption spectrum maximum (a): 1 DNA, 2 d(CCCGGGTTTAAA), 3 poly $(\mathrm{dAdT})_{2}, 4 \mathrm{dAMP}, 5 \mathrm{dCMP}, 6 \mathrm{dTMP}$ and $7 \mathrm{dGMP},(b)$ : 1 tRNA, 2 oligoRNA, $32^{\prime} 5^{\prime} A_{3}$, 4 rAMP, 5 rCMP, 6 rUMP, and 7 rGMP on the duration of UV-irradiation (the value of optical density is in from an intact value of the non-damaged sample)

DNA macromolecule is formed in oligo-RNA, tRNA, and poly(rArU). In addition, the wide unstructured band of the unknown nature was observed in the tRNA phosphorescence spectrum. This band could be related to an element of proteins accompanying to tRNA or some complexes inside tRNA. So, despite some similarities in the chemical and partly energy structures in DNA and RNA macromolecules, the different photophysical processes take place in them with, respectively, different spectral manifestations.

At the temperature $T=77 \mathrm{~K}$, the analysis of phosphorescence spectral curves (Fig. $5, b$ ) is somewhat complicated, because the adenine structure practically disappears in the rAMP and $2^{\prime} 5^{\prime} A_{3}$ spectra. However, the spectral regularities described for oligo-RNA, tRNA, and poly $(\mathrm{rArU})$ at $T=4.2 \mathrm{~K}$ are stored at $T=77 \mathrm{~K}$.

The comparative investigations of the absorption spectra of the samples of DNA, RNA, poly-, oligo- and mononucleotides during the photodamage by ultraviolet light of a Hg-lamp DRT-1000 were carried out. It was pre-

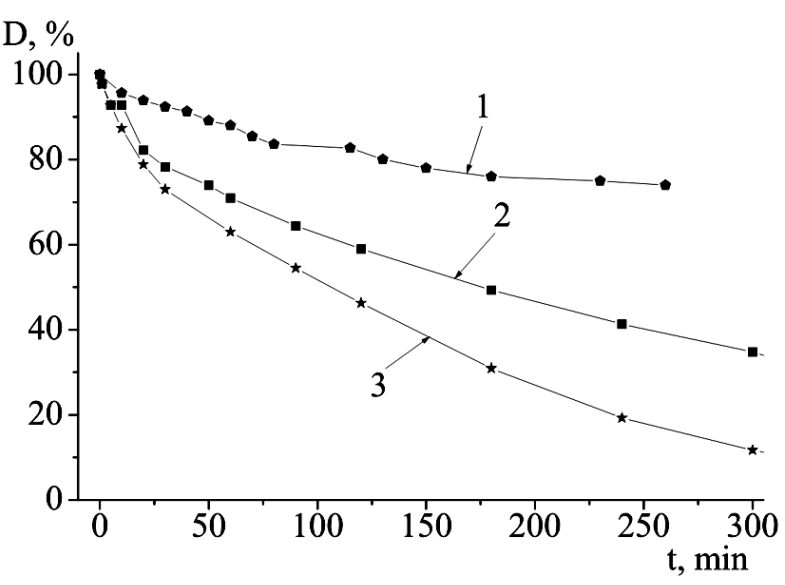

Fig. 7. Dependences of the optical density of the long-wave absorption spectrum maximum on the duration of UV-irradiation: 1 DNA, 2 tRNA, 3 oligo-RNA

viously found [5-7] that dAMP and compounds that contain AT-sequence (DNA, d(CCCGGGTTTAAA) and poly $\left.(\mathrm{dAdT})_{2}\right)$ are significantly more photostable than other deoxyribonucleotides. This is proved by the fact that the curves of optical density changes with time for DNA, d(CCCGGGTTTAAA), poly $(\mathrm{dAdT})_{2}$, and dAMP (Fig. 6, a, curves 1-4) after $250 \mathrm{~min}$ of the exposure are within $80 \div 100 \%$, while, for dCMP, dTMP, and dGMP (Fig. 6, a, curves 5-7), the optical density decreases to $10 \div 30 \%$ at the same time. The last gives the evidence of the less photostability of dCMP, dTMP, and dGMP. The similar situation is observed for RNA and ribonucleotides: the optical density of rCMP, rUMP, and rGMP (Fig. 6, b, curves 5-7) is decreased faster than that for the compounds containing adenosine (RNA, $2^{\prime} 5^{\prime} A_{3}$ and rAMP (see Fig. 6,b, curves 1-4)). The adenosine base in DNA and RNA is the most stable. Thus, in the RNA macromolecule, the mechanism (like in DNA) of self-protection against external negative influences is realized. The spectral manifestation of this mechanism is the localization of triplet excitons (with the following deactivation by the phosphorescence emission) on the most photostable base of the RNA, namely, the adenosine base.

Comparing the dynamics of photodamage of DNA and RNA, as well as the corresponding (deoxy)ribonucleotides, it appears that DNA is more photostable than RNA. This is proved by the fact that the optical density of DNA (Fig. 6,a, curve 1; Fig. 7, curve 1) during $300 \mathrm{~min}$ varies from 100 to $80 \%$, while the optical density varies: for tRNA during $180 \mathrm{~min}$ from 100 to $60 \%$, for oligo-RNA - from 100 to $40 \%$ (Fig. 7 , curves 2 and 3). The change of the 
optical density with the time of irradiation for the ribonucleotides (Fig. 6,b, curves $4-7$ ) is decreased faster than that for the corresponding deoxyribonucleotides (Fig. 6,a, curves 4-7). This is the evidence of that the ribonucleotides (RNA bases) are less photostable than the corresponding deoxyribonucleotides. Thus, DNA is more photostable than RNA not only due to the presence of two strands, but also due to the greater photostability, in fact, of the $\pi$-electron system.

\section{Conclusions}

Summarizing the results of our previous works [5-9] and those obtained in the present investigation, we can confirm the following:

1. The nucleotides are practically independent absorbing centers in DNA/RNA and can be used to build the hierarchy of the energy levels of these biomacromolecules.

2. In both DNA and RNA biomacromolecules, the displacement of energy levels assists to the one-way triplet electronic energy transfer from the cytidine cell along the biomacromolecule to the adenosine cell.

3. The capturing centers of triplet electronic energy excitations are: in the DNA - complex like the exciplex formed by neighbor adenosine (A) and thymidine (T) cells; in the RNA - mainly adenosine cells (the phosphorescence emission of the traps of the unknown nature was additionally observed only in tRNA).

4. The mechanism of self-protection of DNA and RNA against external negative influences is realized by the triplet electronic excitation energy transfer to the centers: AT-sequences in DNA and adenine bases in RNA. These centers are the most photostable as compared with other nucleotide-bases.

5. Despite some similarities in the chemical and partly energy structures, DNA is more photostable than RNA, the deoxyribonucleotides are more photostable than the corresponding ribonucleotides.

The authors are sincerely grateful to Prof. V.I. Melnik and V.P. Vorobyov for the support and valuable ideas in the performance of this work, Prof. H. Suga, Dr. Z.Yu. Tkachuk, and Dr. I.Ya. Dubey for the samples of the biological compounds.

1. A. Bersohn and I. Isenberg, J. Chem. Phys. 40, 3175 (1964).

2. R.O. Rahn, R.G. Shulman, and J.W. Longworth, J. Chem. Phys. 45, 2955 (1966).
3. A.A. Lamola, M. Gueron, T. Yamane, J. Eisinger, and R.G. Shulman, J. Chem. Phys. 47, 2210 (1967).

4. M. Gueron, J. Eisinger, and R.G. Shulman, J. Chem. Phys. 47, 4077 (1967).

5. V. Yashchuk, V. Kudrya, M. Losytskyy, H. Suga, and T. Ohul'chanskyy, J. Mol. Liq. 127, 79 (2006).

6. V.M. Yashchuk, V.Yu. Kudrya, M.Yu. Losytskyy, I.Ya. Dubey, T.Y. Ohulchanskyy, H. Suga, and S.M. Yarmoluk, Sci. Notes of the Nat. Univ. "Kyiv Mohyla Academy": Phys. and Math. 51, 48 (2006).

7. V.M. Yashchuk, V.Yu. Kudrya, M.Yu. Losytskyy, I.Ya. Dubey, and H. Suga, Mol. Cryst. Liq. Cryst. 467, 311 (2007).

8. V.M. Yashchuk, V.Yu. Kudrya, S.M. Levchenko, and N.V. Yevtushenko, Sci. Notes of the Nat. Univ. "Kyiv Mohyla Academy": Phys. and Math. 61, 39 (2007).

9. V.M. Yashchuk, V.Yu. Kudrya, S.M. Levchenko, Z.Yu. Tkachuk, D.M. Hovorun, V.I. Mel'nik, V.P. Vorob'yov, and G.V.Klishevich, Mol. Cryst. Liq. Cryst. 535, 93 (2011).

10. I.S. Gorban', V.M. Yashchuk, A.Y. Kalnitskiy, and V.P. Naidyonov, J. Appl. Spectr. 47, 96 (1987) [in Russian].

11. I.S. Gorban', Yu.P. Piryatinsky, and V.M. Yashchuk, Molec. Mater. 1, 241 (1992).

Received 23.09.11

СПЕКТРАЛЬНІ ВЛАСТИВОСТІ ТА ФОТОСТАБІЛЬНІСТЬ ДНК, РНК ТА ОЛІГОНУКЛЕОТИДІВ

В.Ю. Кудря, В.М. Ящук

Р е $з$ ю м е

У даній роботі обговорено результати порівняльних досліджень оптичного поглинання, люмінесценції та фотостабільності біомакромолекул (ДНК, РНК), а також синтетичних політа олігонуклеотидів. Доведено, що окремі нуклеотиди є основними поглинаючими центрами в ДНК та РНК. Підтверджено, що основними пастками триплетних збуджень, що відповідають за фосфоресценцію ДНК, є АТ-комплекси. На відміну від ДНК основними пастками триплетних збуджень в PHK є аденозинові бази. Останні є найбільш фотостабільними до УФ-опромінення на відміну від інших нуклеотидів і у ДНК, і у РНК. Факт фотостабільності аденозинових баз та АТ-комплексів доводить існування механізму самозахисту ДНК/РНК проти УФ-опромінення. Показано, що дезоксирибонуклеотиди є більш фотостабільними, ніж відповідні рибонуклеотиди. Отримані результати є свідченням того, що ДНК більш фотостабільна, ніж РНK. 